SHS Web of Conferences 10, 00006 (2014)

DOI: $10.1051 /$ shsconf/20141000006

C Owned by the authors, published by EDP Sciences, 2014

\title{
Theoretical models for development competence of health protection and promotion
}

\author{
J. Cesnaviciene ${ }^{1}$ and V. Gudzinskiene ${ }^{2}$ \\ ${ }^{1}$ Lithuanian University of Educational Sciences, Lithuania \\ ${ }^{2}$ Mykolas Romeris University, Lithuania
}

\begin{abstract}
The competence of health protection and promotion are mentioned in various legislative documents that regulate areas of education and health policy. The researches on health conditions of Lithuania Country's population disclosed the deteriorating health status of the society, even of the children. It has also been found that the focus on health education is not adequate. The number of National and International health programmes have been realized and educational methodological tools prepared in Lithuania, however the insufficient attention to the health promotion models is been noticed. The objective of this article is to discuss the theoretical models used in health education field. The questions to be answered: what theoretical models are used in order to development competence of health protection and promotion? Who does employ particular models? What are the advantages of various models? What conceptions unite and characterize theoretical models?

The analysis of scientific literature revealed the number of diverse health promotion model; however none of them is dominant. Some of the models focus on intrapersonal, others on interpersonal or community level but in general they can be distinguished as cognitive - behavioural models which are characterized by three main conceptions: 1) the healthy living is determined by the perceived health related knowledge: what is known and understood would influence the behaviour; 2) the knowledge in healthy living field is essential but insufficient condition for behaviour change; 3 ) the great influence to healthy living life style is done by perception, motivation, skills and habits as well as social environment. These are the components that are typical to all theoretical models and that reflect the hole of the conditions influencing healthy living.
\end{abstract}

\section{Introduction}

The relevance of the subject is distinguished by some aspects. First of all, in the age of globalization the health is one of the most important factors that can influence the process of nations' progress, well-being of the society and individual. It is commonly agreed that the biggest impact on the health status of the individual is done by the life style of the person. The investment into health education and improvement of healthy living competences is more effective than the paying the costs of the medical treatment of those with medical pathologies. This is why the main objective of the development of society is the attention to health related areas. On another hand, the aging society and the healthcare as well as the lack of appropriate health education competences raise great threats to society. The 2012 had been announced

This is an Open Access article distributed under the terms of the Creative Commons Attribution License 4.0, which permits unrestricted use, distribution, and reproduction in any medium, provided the original work is properly cited. 


\section{SHS Web of Conferences}

European Year for Active Ageing and Solidarity between Generations and the attention has been paid to healthy ageing and the conditions for it. The urgency is also influenced by the demographical changes in developed countries: the number of children is decreasing and the number of elderly people rising. R. Gurevicius and J. Jaselioniene (2012) stated that the number of older than 65 year old people will reach one fourth of the Europe's populations. By the 2050 this age group will increase by 70 percent, while 80 years and above - by 170 percent. This phenomenon, of course, is related to the great challenge of the $21^{\text {st }}$ century - meeting the expectation of the society. One of the main objectives is to adapt the health protection system to the needs of the ageing population and supporting them in the communities. The predictions of the EU Statistics' department revealed the rapid ageing of Lithuanian society too by the 2060 almost 37 percent of Lithuania's population will be older people, while the average of 27 EU countries would be 35 percents.

The minimal expenses on the negative aspects of the ageing population and maximum benefits to the society and individuals of longer expected life are the main challenges in light of the demographical ageing. This is why it is so vital to develop health education and healthy living competences. The lack of competences of health protection and promotion among Lithuania's population is characterized by the dynamics of number of death causes (according to the sex and age); however the structure of the death causes has not changed since 2001 - the majority of the people die because of 3 main causes - deceased related to blood circulation. Over the half of the deaths in 2011 (56.3 percent) (56.1 percent in 2010). The sickness rate in the period of 2001-2010 had periodically grown. The sickness rate is especially high in the age group of 65 year olds and above - 6604.7 in 100000 population in 2001 and 7091 in 2010. As it is well known, the life style of the individuals and the competence of health protection and promotion are directly associated with heart and blood circulation conditions.

The lack of competences of health protection and promotion is also illustrated by the fact that since the 2006 sickness rate of mental and behavioural disorders had gone up scientifically. 2359.8 per 100000 registered in 2006, 2902.8 in 2008 and 2558.1 in 2010. The sickness rate of digestive system diseases had increased from 4170.9 per 100000 in 2001 to 5249.2 in 2010 (29 example). The sickness rate in the over 65 age group has increased from 4057.4 in 2001 to 5061.6 in 2010. It is obvious that lacking effective health education and programmes developing healthy living competences would not be realistic to achieve better results. According to the experts the main strategy would be establishing successful healthy ageing conception. Healthy ageing - is optimal mental, physical and social well-being as well as functional maintenance. The EU supports member countries that encourage healthy ageing using primary and secondary prevention initiatives in order to develop healthy living competences.

The integration of elderly people into the society is partly limited by the attitudes towards the physical and psychological health conditions of older generation in the society as well as the social environment and conditions (WHO Active Ageing, 2002). It is needed to promote different concept of the ageing phenomenon and aim for the inclusion of older people into active participation in the family and the community life, labour market; to fight the poverty and social exclusion. Along with the increasing number of older people is essential to improve the competences of all age groups in the field of healthy living and health education and relative health education models.

Thirdly, the image of the modern pupils provided in the Curriculum Framework for Primary and Basic (Lower Secondary) Education (2008) - self confident, active, communicable and cooperative, ready to learn and gained common basics and competences of vital life areas. In order for this vision to become a reality it is essential to ensure a good health of every child that could guarantee continuous participation in the education process. However the results of the pupil life styles researches and findings of the Regional Office for Europe of World Health Organization international surveys (Currie et al., 2008; Currie et al., 2012) revealed that the life style of Lithuania's pupils is not really beneficial to their health and does not always meet the principles of healthy living.

Fourthly, the findings of the research confirm that health education at school receives insufficient attention (Zaborskis, Lenčiauskienė, Klibavičius, 2005; Gudžinskienė, Česnavičienė, Suboč, 2007), 
Int. Conf. SOCIETY. HEALTH. WELFARE.

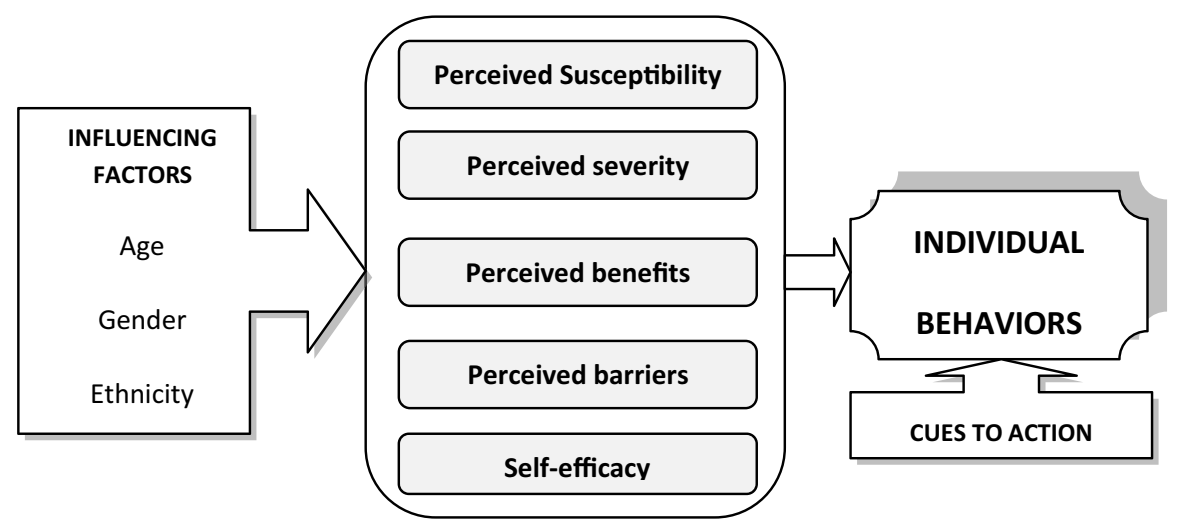

Figure 1. Health Belief Model (by Janz, Becker, 1984).

learners lack knowledge (Jociutè, Zaborskis, 2000) and skills (Gudžinskienė, 2010) of health protection and promotion, whereas graduates' need for the knowledge on some health aspects remains unsatisfied (Juškeliené, Ustilaité, 2009). Therefore, learners' purposive approach towards their health has not become a life norm (Gudžinskienè, 2010). This situation explores the contradictions between the need to develop competences of health protection and promotion among pupils and other age groups as the mean of the assumption of their healthy living and insufficient attention to this area in the existing educational practise. This would also reveal the relevance of the article and allows us to defining scientific proposition characterised by the questions - what theoretical models are used to improve and develop competences of health protection and promotion? Who are the ones to use these models most often? What are the advantages of the different models? What conceptions characterize and generalize these theoretical models?

Research area - the theoretical models used in the field of develop competences of health protection and promotion.

The goal of the research - to discuss the theoretical models of competences of health protection and promotion development as well as the characteristics of their use.

The research methods - analysis of scientific literature in the field of health promotion theoretical models, the systemic analysis of available information from website sources, interpretation, assumption and generalization, synthesis of the information.

\section{The health promotion theoretical models and their characteristics}

One of the oldest known (from the 50-ies of the XX century) interpersonal theoretical health promotion model is the Health Belief Model (Fig. 1), founded by USA social psychologists G. Hochbaum and I. Rosenstock. Later on this model was explicated by M. Becker, who has stated that the change in every person's behaviour is influenced by: 1) motivation, 2) believe in the benefits of the behaviour change and expectation of none or very few negative effects, 3) capacity for change (Janz, Becker, 1984).

Realising the Health Belief Model in the process of education, encouraging people to change usual behaviour into the healthy one, the most important is the understanding of people's vulnerability and the effects of the negative behaviour on people's well-being. The vital cognitive competence component in this stage is the knowledge. Having assessed possible effects on their health, people would realize the benefits of healthy life style which would overcome possible obstacles. Moreover, another very important factor is the intention for change and self confidence. These two aspects of the change in behaviour would be connected by one emotional component of the competence - the attitudes. 




Figure 2. Integrated Behavior Model (by Fishbein, 2000).

The support provided by the social environment is also very important if we want the behaviour to change. The authors of this model had also mentioned few other characteristics or factors that could have the effect on the understanding and believing in healthy living. This can depend on their age, sex, knowledge already gained etc.

In spite of the fact the Health Belief Model has been created on the basis of the popular biomedical health concept and the tactics of intimidation widely used in the educational practise (was originally designed for the prevention of tuberculosis, promotion of vaccination) it is still very widely used in the field of cancer related diseases prevention (Abraham, Sheeran, 2005; Champion, Sugg Skinner, 2008; Želvienė, 2007), AIDS and harmful sexual behaviour or addictions prevention (Lin, Simoni, Zemon, 2005; Abraham, Sheeran, 2005; Champion, Sugg Skinner, 2008; Sharma, 2011), prevention of osteoporosis (Hazavehei, Taghdisi, Saidi, 2007; Edmonds, 2009), changing feeding patterns (Nejad, Wertheim, Greenwood, 2005; Gamboa Acuña, 2010). In general it is important to have in mind that this model is usually used by the medical and public health professionals in the field of adult behaviour change,

The Health Belief Model is based on the concept of the vulnerability of the person (fear for the health) and the behaviour that can help avoid the illnesses and their negative effects). The obvious benefits are the factors influencing positive change in behaviour, which is on another hand initiated by the healthy life style.

Another intrapersonal health promotion theoretical model is - Integrated Behavior Model (Fig. 2), combining two theories that were created in the 8 ties and p-ies of the $20^{\text {th }}$ century. I. Ajzen and M. Fishbein created Theory of Reasoned Action and Theory of Planned Behaviour. These theories offer theoretical constructions of the individual factors that have a motivating stimulation on ones behaviour (Fishbein, 2000; Montaño, Kasprzyk, 2008).

Using these models (taking into account internal factors such as sex, age, nationality, attitudes towards the objective) and employing individual believes and behaviour norms, in purpose to build healthy living competences, attitude towards ones behaviour and believes is changed (emotional component of the competences). These changes would motivate to follow the healthy living principles. Moreover the success in this field is also influenced by the self-confidence, believing in the effectiveness of the behaviour changes. In general, the healthy living attitudes are reinforced by the capacity to control own behaviour and the social norms existing in the society. The cognitive and perceived intention along with the healthy living skills and the positive impact of social environment would lead towards the change of behavioural patterns. 
Int. Conf. SOCIETY. HEALTH. WELFARE.

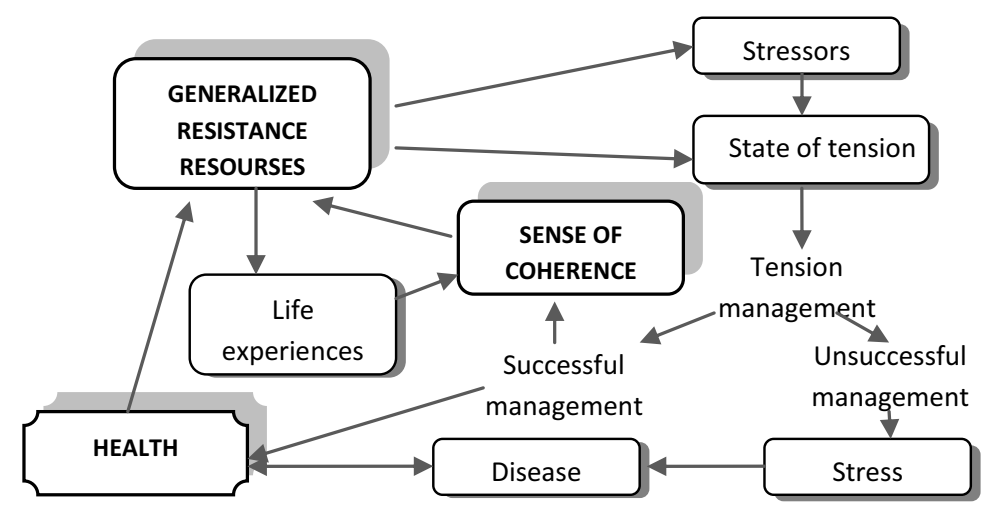

Figure 3. The Salutogenic Model (by Antonovsky, 1996).

The number of scientific studies had revealed success of the Integrated Behavior Model in the field of changing nutrition habits (Nejad, Wertheim, Greenwood, 2005; Conner, Sparks, 2005; Fila, Smith, 2006), promoting physical activities (Conner, Sparks, 2005), prevention of harmful behaviour (Conner, Sparks, 2005; Žardeckaitè-Matulaitienė, 2008; Malmberg et al., 2010), prevention of AIDS and risky sexual behaviours (Montaño, Kasprzyk, 2008). In spite of the wide use of this model in the field of building healthy life style habits, it is also criticized because it is not always possible to explain changing behaviour on the basis of this theory. The difficulties using this model in the process of the education arise because of the unavailability of practical links to the theoretical background (Kanekar, Sharma, 2007).

The very important factor in using the Integrated behaviour model in the health education and development of healthy living competences becomes the intention to change the behaviour and this hanged is based on the attitudes towards healthy living, behaviour norms and belief in the effectiveness of such changes.

Another very interesting and modern intrapersonal health education model which is particularly popular in Sweden, Finland and Germany's education systems is The Salutogenic Model (Fig. 3).

The theoretical basis for this model is the Theory of Salutogenesis, developed by A. Antonovsky in the 90-ies. This model is distinguished by the focus rather on to the health support factors and resources that could help to fight the medical conditions (personal physical characteristics, intellect, attitudes, economical capacities, socio - cultural factors, etc.). According to A. Antonovsky (1996) the health is understood as the mediator between the wellbeing while the sense of coherence which is evolved in the school age is the core of this model. It is an important psychological factor that would influence the psychological and physiological wellbeing. The sense of coherence is characterized by three components: perception of the activity (cognitive), significance of the activity (motivation) and capacity to control own behaviour (behavioural). These specific components of the Salutogenic model will lead to the motivation of the pupils to change the behaviour and use internal resources that prevent the effects of the risky behaviour. The pupils with the higher level of sense of coherence would understand the mean of their actions and rely on their capacities - speaking in other words - they will be the ones to care for their health, participate in the health programmes and change the life styles and generally overcome the negative effects of the frustrating factors. On another hand the pupils with lower level of internal drama would be liable to risky habits and "unhealthy" behaviour.

The integration of Salutogenesis theory into the education systems explore and strengthen health education and health literacy conceptions and this is the main reason why this model relates to the norms of Learning through life concept (Becker, Glascoff, Felts, 2010; Lindström, Eriksson, 2006, 2011). 


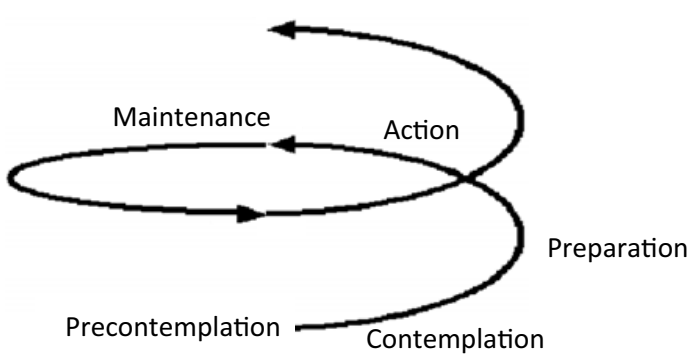

Figure 4. The Transtheoretical Model of Behaviour Change (by Prochaska, Redding, Evers, 2008).

The main and most important aspect of Salutogenic model is the Sense of coherence. The simulation of appropriate environment that enforces high level of internal harmony is essential in this understanding: the social environment should strengthen the good relationships of all participants of educational processes, their communication and cooperation culture based on emotional support. Even more important is that the decisions to change behavioural patterns should have been made by the person himself. Only this can lead to effective and realistic changes.

The Transtheoretical Model of Behaviour Change should also be mentioned in this article. It is also intrapersonal theoretical model created by J.O. Prochaska and C. DiClemente (1983). These authors claim that the change of behaviour is not a solitary action but ongoing helical process which can last for months or even years. The 6 levels of behaviour change process should be gone through on the basis of this model (Fig. 4). The first level or stage is the state precontemplation, when the pupils had no intentions to change their behaviour in the next half a year. This can be because of the lack of information about harmful consequences of the current behaviour. The individuals who tried to change their behaviour but were not successful would also be returned to this stage.

The second stage is contemplation. The pupils are better informed about the effects of their risky behaviour to their wellbeing and clearly realise their vulnerability. They are ready to change their behaviour in the near future. In spite of the good intention the lingering of the actions, lack of confidence in the capability to change the risky behaviour. The third stage of the model is the preparation to change the behaviour and the life style in the nearest month. The people in this stage would have already got action plan and even try to fulfil this plan in order to change the lifestyle. The fourth stage is the activities and the obvious changes in behaviour within the half a year time. The efficiency of the activities usually is very high; however the risk of returning to previous behaviour exists due to the pressure of the social environment or failures experienced. The reassurance and support of social environment is very important in this stage. The fifth stage is maintenance or strengthening of the changes in behaviour. This stage would take no longer than half a year and should proceed to the final stage - withdrawal, when the behaviour of the individuals had changed and there are no possibilities to return to the previous life style patterns.

The Transtheoretical Behaviour Change Model is widely used in the field of prevention of harmful behaviour and habits (Prochaska, Redding, Evers, 2008), prevention of bullying and suicide (Sutton, 2005; Prochaska, Redding, Evers, 2008), promotion of physical activeness (Ronda, Van Assema, Brug, 2001; Adams, White, 2003; De Bourdeaudhuij et al., 2005; Prochaska et al., 2008), change of nutrition patterns (Wilson, Schlam, 2004; Prochaska, Redding, Evers, 2008).

The Precaution Adoption Process Model was first introduced by N. Weinstein in 80-ies of $20^{\text {th }}$ century (Weinstein, Sandman, 1992). This model (Fig. 5) is basically similar to the one described by J.O. Prochaska and C. DiClemente's model. The difference is its linear background. The primary situation is when pupils do not realize the problem (the effects of problematic behaviour on the health) or know but do not pay any attention. The provision of information is essential in this stage - it can 
Int. Conf. SOCIETY. HEALTH. WELFARE.

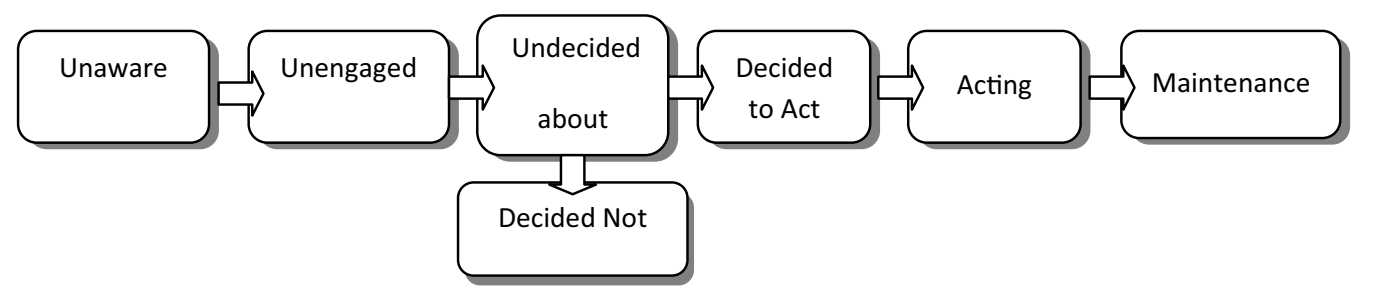

Figure 5. The Precaution Adoption Process Model (by Weinstein, Sandman, 1992).

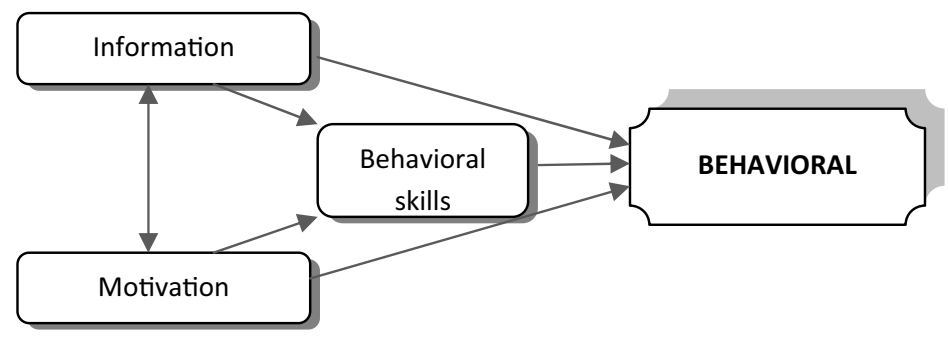

Figure 6. The Information-Motivation-Behavioral skills model (by Fisher, Fisher, Harman, 2003).

motivate to take actions or some precaution measures in order to avoid negative effects. The new and positive behaviour patterns are secured in the final stage.

The prevention of cancer related diseases, contagious infections, osteoporosis is implemented on the basis of the Precaution Adoption Process Model (Sutton, 2005; Weinstein, Sandman, Blalock, 2008).

It is very important to focus on the first stages of the two models mentioned above. This would ensure the higher motivation to change the behaviour patterns. On another hand the activity itself is also very important and the reassurance of the social environment (colleagues, community members, family, and friends) is also essential.

The most recent intrapersonal theoretical model which is designed to improve the health education and healthy living competences is The Information-Motivation-Behavioral skills model (Fig. 6). The authors of the model claim that the healthy life style related information, skills and motivation are very important factors in order to strive for the positive changes in behavioural patterns. The main point in this perspective is the spread of the purposeful information related to the health improvement and strengthening among the target groups. On another hand, the knowledge itself will not be useful if the motivation of the individual is not strengthened and the values are not developed.

The authors of this model draw attention to the need of the information to be simple but clear and directly connected to the changeable behaviour of the person. The motivation to change the problematic behaviour patterns should be predetermined by individual attitude towards the behaviour and the perception of health vulnerability as well as reassurance and support provided by the social environment. The realization of the Information-Motivation-Behavioral skills model will constitute to the development of the healthy living and other health related competences. It is believed that the properly informed individuals will be well motivated to take actions and will have developed healthy living skills.

It is essential to understand (Fisher, Fisher, Harman, 2003) that the educational process should contain all three components of the model, only this can secure successful and effective changes. The successful HIV and AIDS prevention is been accomplished on the basis of The Information-MotivationBehavioral skills model. This is the main area of use of this model (Fisher, Fisher, Harman, 2003; 
SHS Web of Conferences

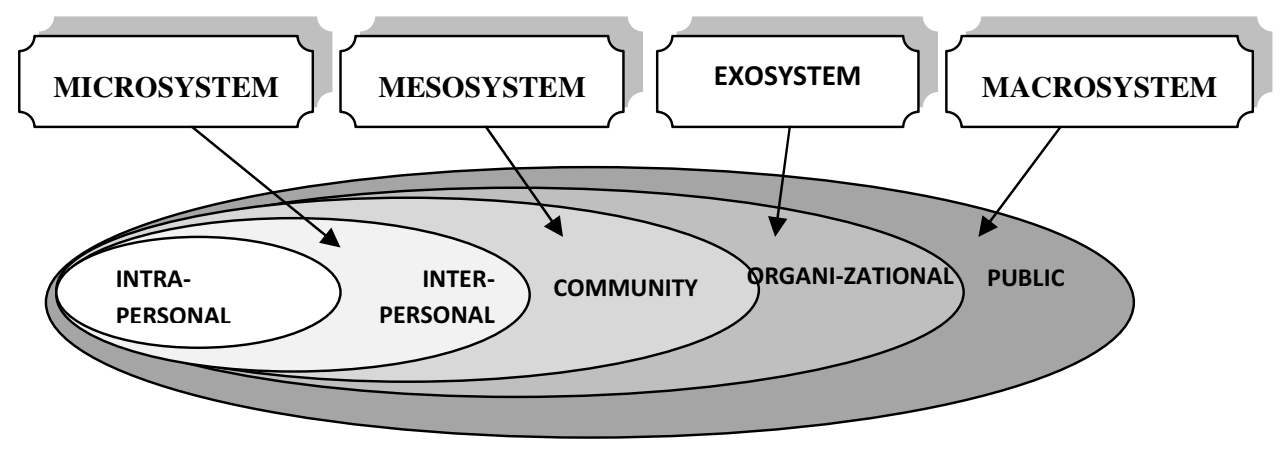

Figure 7. Social Ecological Model (by Bronfenbrenner, 1994; McLeroy et al., 1988).

Amico, Toro-Alfonso, Fisher, 2005), however proved to have good results in other areas too (alcohol misuse prevention and building healthy diet habits).

The realization of Information-Motivation-Behavioral skills model is based on the knowledge and information about healthy living. The information is vital to the motivation and development of healthy living skills. These three linked components of the model empower the individual to change the behaviour towards the positive direction.

The best known interpersonal theoretical model is The Social influence model. It is based on A. Bandura's Social cognitive theory (70-ies of the $20^{\text {th }}$ century), that focuses on the learning through the observation. It explains how people learn new means of behaviour, emotional reactions, form their attitudes and behaviour based on the "model" observed. According to this theory the individual adopts observed social behaviour or roles - through the formation of cognitive frame in the permanent memory, which can be mimicked in similar to observed situation (Bandura, 1998).

Social influence model discloses the links among the healthy life style, personal characteristics and social environment. Personal characteristics are understood as the knowledge of the healthy living, capacities to realize the consequences of own behaviour, learning healthy living behaviour through the observation of others, self confidence and ability to overcome health threatening factors along with the capacity to control and analyze own behaviour. The most important point here is obviously the social environment (family members, friends, colleagues) as they are the ones the observer can mimic and learn behaviour models from. The educational process based on the Social influence model focuses both on personal characteristics of the individual and people from his social environment.

A.L. McAlister, Ch.L. Perry and G.S. Parcel (2008) had carried out the meta-analysis of the number of researches and it has proved the effectiveness of applying social cognitive theory's principles in the area of chronicle diseases prevention, substance misuse and smoking prevention or the physical activeness promotion. The realisation of the Social influence model in the perspective of harmful behaviour among teenagers had been studied by H. De Vries and others (1994), K. ŽardeckaitèMatulaitienè (2008), P.D. Vitoria and others (2009), R. Vilkonis (2004).

In conclusion we can say that Social Cognitive theory and the Social influence model focus accentuate the influence of social environment and individual characteristics on the behaviour patterns changes or healthy living education in general.

We certainly agree that every person is the member of wider community - the conditions to realize community based health strengthening and educational programmes and models are often organized within the local communities. The best known community model is Social Ecological Model (Fig. 7). It also relies on three theoretical backgrounds.

The first theoretical basis for this model is Ecological Systems Theory (Bronfenbrenner, 1994). The education process based on this theory is focusing on the relations of the individuals and the social environment. Introducing this theory the author offered the systematic approach which focuses on 


\section{Int. Conf. SOCIETY. HEALTH. WELFARE.}

the reciprocity of the different areas (micro-, meso-, exo- and macro- levels). The individuals as the elements of the system and the factors influencing the changes in social behaviour are not treated as the isolated unit but rather as the part of the wider structure. Microsystem is the closest environment around the individuals (the family in most cases). The family is responsible for the formations and development of the healthy living attitudes and care for the health as well as the healthy life models are sought here. Mesosystem (close friends, neighbours, colleagues and peers) in direct connection with micro level would form the healthy living as the mean of social behaviour. The teachers can be the models of some behaviour on one hand but also they are the source of formal information on healthy living and supports system to build and develop appropriate healthy living skills and habits. The peers and friends as the representatives of mezzo system become the essential and important source of selfesteem and self confidence to the person. Exosystem is indirect, a bit distant social environment which is formed by family friends, relatives, social services representatives. The person in this system is not an active participant but the system meets his or her needs, stimulates the development etc. The very distinguishable and interesting function of the exosystem is the support of the development of healthy living habits thought the micro level. Macro system is rather wide and distant circle that consists of nation's culture, traditions, social norms and models. It influences other three levels and contributes to the healthy living attitude and tradition development.

The second theoretical background for the model is Ecological Health Behaviour model (McLeroy et al., 1988). This model describes five levels that have influence on healthy living: intrapersonal, interpersonal, community, agency and society. Intrapersonal level of the model is the central one and focuses on individual factors that can effect healthy living (knowledge, attitude, believes, motivation, skills, capasities, sex, age, education, social and economic status etc). Interpersonal level covers the relationships between pupils and their closest environment (family, friends, and peers) that support the changes in behaviour. Community level is the social networks and norms that formally or informally exist among the pupils and within their close environment or community. The agency level consists of the orders and rules that limit or stimulate appropriate behaviour of the pupils. The society level includes the local, regional or national policy that gives the support to healthiness related activities.

The third background is Socio-ecological model for health development (Stokols, 1996), which defines main presumptions of Social-ecological model. It is claimed that the number of the various factors existing within the social environment have influence on human behaviour. The interactions of the individuals are the complex social environment that can be distinguished by the different levels of organization. This model has been successfully used in changing the diet habits (Robinson, 2008), smoking prevention (Kothari et al., 2007). On the experience of these successful uses it is also possible to adapt the use of the model in other specific areas.

The various theoretical health related competences development and healthy living education models can be employed, however based on their focus these can be divided into, individual, interpersonal and community levels.

\section{Conclusions}

The analysis of the scientific material has revealed that the most often used and most successful models for healthy living competences development and formation of healthy life styles were these intrapersonal models: The Health belief model, The Integrated behaviour model, The Salutogenic Model, The Transtheoretical Model of Behaviour Change, The Precaution Adoption Process Model, and The Information-Motivation-Behavioral skills model. The Social Influence model is one of the most effective interpersonal level theoretical models. Social Ecological Model is very successful in community perspective.

The variety of the healthy living competences development and health related education models exists, however none of them became a universal and dominant. Some of the models are focused 


\section{SHS Web of Conferences}

on the individual level, others on interpersonal or community levels, however generally these can be described as cognitive behavioural, that are linked with three main conceptions: 1) the healthy life style is conditioned by the perception of the knowledge: the things that person acknowledges and accepts will influence his behaviour; 2) healthy life style related knowledge is vital but incomplete condition for the change of behaviour patterns; 3) the enormous influence towards the healthy life style is done by perception, motivation, skills and habits as well as social environment. These are the main and general components that reflect the system of the factors essential for the development of health related competences and healthy life styles.

Taking into account some certain advantages of specific theoretical models the multidiscipline professionals can use different health related competences development and health education models and that is most important - if used properly - achieve great results in prevention and risky behaviuor exchange fields.

\section{References}

[1] Abraham, Ch.; Sheeran, P., 2005. The Health Belief Model. In Predicting Health Behaviour: Research and Practice with Social Cognition Models. Ed. by M. Conner, P. Norman. New York: Open University Press, pp. 28-80.

[2] Amico, K. R.; Toro-Alfonso, J.; Fischer, J. D., 2005. An empirical test of the Information, Motivation and Behavioral Skills model of antiretroviral therapy adherence. AIDS Care, vol. 17 (6), pp. 661-673. [accessed: 2013-11-18]. http://jtoro.uprrp.edu/Publicaciones.htm.

[3] Antonovsky, A., 1996. The salutogenic model as a theory to guide health promotion. Health Promotion International, vol. 11 (1), pp. 11-18. [accessed: 2013-11-18]. http://heapro. oxfordjournals.org/.

[4] Bandura, A., 1998. Health Promotion from the Perspective of Social Cognitive Theory. Psychology and Health, vol. 13, pp. 623-649. [accessed: 2013-11-18]. http://des.emory.edu/ mfp/BanduraPubs.html.

[5] Becker, C. M.; Glascoff, M. A.; Felts, W. M., 2010. Salutogenesis 30 Years Later: Where do we go from here? International Electronic Journal of Health Education, vol. 13, pp. 25-32. [accessed: 2013-11-18]. http://www.aahperd.org/aahe/publications/iejhe/.

[6] Bronfenbrenner, U., 1994. Ecological models of human development. In International Encyclopaedia of Education, vol. 3, [accessed: 2013-11-18]. http://www.psy.cmu.edu/ siegler/ 35bronfebrenner94.pdf.

[7] Champion, V. L.; Sugg Skinner, C., 2008. Health Belief Model. In Health behavior and health education: theory, research, and practice. Ed. by K. Glanz, B. K. Rimer, K. Viswanath. San Francisco: Jossey-Bass, 2008, pp. 45-65.

[8] Conner, M.; Sparks, P., 2005. Theory of Planned Behaviour and Health Behaviour. In Predicting Health Behaviour: Research and Practice with Social Cognition Models. Ed. by M. Conner, P. Norman. New York: Open University Press, pp. 170-222.

[9] Currie C., Zanotti C., Morgan, A.; Currie, D.; De Looze M.; Roberts, Ch.; Samdal, O.; Smith, R.; Barnekow, V., 2012. Social determinants of health and well-being among young people. Health Behaviour in School-aged Children (HBSC) study: international report from the 2009/2010 survey (Health Policy for Children and Adolescents, No. 6). Copenhagen, WHO Regional Office for Europe. [accessed: 2013-11-18]. http://www.hbsc.org/publications/international/.

[10] Currie, C.; Gabhainn, S. N.; Godeau, E.; Roberts, Ch.; Smith, R.; Currie, D.; Picket, W.; Richter, M.; Morgan, A.; Barnekow, V., 2008. Inequalities in young people's health: international report from the HBSC 2006/06 survey (Health Policy for Children and Adolescents, No. 5). Copenhagen, WHO Regional Office for Europe. [žiūrèta 2009-06-20]. Prieiga per internetą: http://www.hbsc.org/publications/international/. 


\section{Int. Conf. SOCIETY. HEALTH. WELFARE.}

[11] De Vries, H.; Backbier, E.; Dijkstra, M.; Van Breukelen, G.; Parcel, G.; Kok, G., 1994. A Dutch social influence smoking prevention approach for vocational school students. Health Education Research, vol. 9 (3), pp. 365-374. [accessed: 2013-11-18]. http://her.oxfordjournals.org/.

[12] Edmonds, E. T., 2009. Osteoporosis Knowledge, Beliefs, and Behaviors of College Students: Utilization of The Health Belief Model. A Dissertation Submitted in partial fulfilment of the requirements for the degree of Doctor of Philosophy in the Department of Health Sciences in the Graduate School of The University of Alabama. 159 p. [accessed: 2013-11-18]. http://acumen.lib.ua.edu.

[13] Fila, S. A.; Smith, CH., 2006. Applying the Theory of Planned Behavior to healthy eating behaviors in urban Native American youth. International Journal of Behavioral Nutrition and Physical Activity, vol. 3, 11 p. [accessed: 2013-11-18]. http://www.ncbi.nlm.nih.gov/ pmc/issues/126575/.

[14] Fishbein, M., 2000. The role of theory in HIV prevention. AIDS Care, vol. 12 (3), pp. 273-278. [accessed: 2013-11-18]. http://www.tandfonline.com/loi/caic20.

[15] Fisher, W. A.; Fisher, J. D.; Harman, J., 2003. The information-motivation-behavioral skills model: A general social psychological approach to understanding and promoting health behavior. In Social psychological foundations of health and illness. Ed. by J. Suls, K. Wallston. London: Wiley-Blackwell, pp. 87-106.

[16] Gamboa Acuña, M. E., 2010. Development of a Nutrition Education Program for Hispanic Women of South Carolina Based on Nutrition and Cooking Classes Using the Health Belief Model and the Social Cognitive Theory. A Thesis Presented to the Graduate School of Clemson University. In Partial Fulfilment of the Requirements for the Degree Doctor of Philosophy Food Technology, 163 p. [accessed: 2013-11-18]. http://etd.lib.clemson.edu

[17] Gudžinskienè, V., 2010. Kompetenciju igijimo prielaidos ir sveikatos bei kai kuriu socialiniu kompetenciju raiška: mokslo darbų apžvalga: socialiniai mokslai, edukologija (07 S). Vilnius: VPU 1-kla, 96 p.

[18] Gudžinskienè, V.; Česnavičienè, J.; Suboč, V., 2007. Sveikos gyvensenos ugdymas mokyklose. ŠMM užsakomojo tyrimo ataskaita. [accessed: 2013-11-18]. http://www.smm.lt.

[19] Gurevičius R., Jaselionienè J. Lietuvos gyventojų sveikatos rodikliai ir senstančios visuomenès itaka jụ raidai. Nacionalinès sveikatos tarybos metinis pranešimas - 2012. Sveikas senejjimas nauji iššūkiai Lietuvai. Vilnius, 2012, p. 5-15.

[20] Hazavehei, S. M.; Taghdisi, M. H.; Saidi, M., 2007. Application of the Health Belief Model for Osteoporosis Prevention among Middle School Girl Students. Education for Health, vol. 20, issue 1. [accessed: 2013-11-18]. http://www.educationforhealth.net/.

[21] Janz, N. K.; Becker, M. H., 1984. The Health Belief Model: A Decade Later. Health Education \& Behavior, vol. 11 (1), pp. 1-47. [accessed: 2013-11-18]. http://heb.sagepub.com/ content/11/1/1.short.

[22] Jociutè, A.; Zaborskis, A., 2000. Sveikata stiprinančiu mokyklu veiklos rodikliai. Panevėžys: E. Vaičekausko knygyno 1-kla, 43 p.

[23] Juškelienè, V.; Ustilaitè, S., 2009. Lietuvos 16-19 metụ mokyklą baigiančiụ mokiniụ fizinio aktyvumo ịpročiai visuomenès sveikatos požiūriu. Sporto mokslas, Nr. 1 (55), p. 67-74.

[24] Kanekar, A.; Sharma, M., 2007. Tobacco Prevention Interventions in Adolescents. Californian Journal of Health Promotion, vol. 5 (3), pp. 120-130. [accessed: 2013-11-18]. http://www.csuchico.edu/cjhp/5/3/120-130-kanekar.pdf.

[25] Lin, P.; Simoni, J. M.; Zemon, V., 2005. The Health Belief Model, Sexual Behaviors, and HIV Risk among Taiwanese Immigrants. AIDS Education and Prevention, vol. 17 (5), pp. 469-483. [accessed: 2013-11-18]. http://www.health-psychology.org/pub1.pdf.

[26] Lindström, B.; Eriksson, M., 2011. From health education to healthy learning: Implementing salutogenesis in educational science. Scandinavian Journal of Public Health, vol. 39 (6), pp. 8592. [accessed: 2013-11-18]. http://sjp.sagepub.com. 
[27] Malmberg, M.; Overbeek, G.; Kleinjan, M.; Vermulst, A.; Monshouwer, K.; Lammers, J.; Vollebergh, W. A. M.; Engels, R., 2010. Effectiveness of the universal prevention program 'Healthy School and Drugs': Study protocol of a randomized clustered trial. BMC Public Health, vol. 10, pp. 541-551. [accessed: 2013-11-18]. http://www.biomedcentral.com/.

[28] Mcalister, A. L.; Perry Ch. L.; Parcel G. S., 2008. How Individuals, Environments, and Health Behaviors Interact. Social Cognitive Theory. In Health behavior and health education: theory, research, and practice. Ed. by K. Glanz, B. K. Rimer, K. Viswanath. San Francisco: Jossey-Bass, 2008, pp. 169-188.

[29] Montaño, D. E.; Kasprzyk, D., 2008. Theory of Reasoned Action, Theory of Planned Behavior, and the Integrated Behavioral Model. In Health behavior and health education: theory, research, and practice. Ed. by K. Glanz, B. K. Rimer, K. Viswanath. San Francisco: Jossey-Bass, 2008, pp. 67-96.

[30] Nejad, L. M.; Wertheim, E. H.; Greenwood, K. M., 2005. Comparison of the Health Belief Model and the Theory of Planned Behavior in the Prediction of Dieting and Fasting Behavior. E-Journal of Applied Psychology: Social section, vol. 1 (1), pp. 63-74. [accessed: 2013-11-18]. http://ojs.lib.swin.edu.au/index.php/ejap.

[31] Prochaska, J. O.; Redding, C. A.; Evers, K. E., 2008. The Transtheoretical Model and Stages of Change. In Health behavior and health education: theory, research, and practice. Ed. by $\mathrm{K}$. Glanz, B. K. Rimer, K. Viswanath. San Francisco: Jossey-Bass, 2008, pp. 67-96.

[32] Sharma, M., 2011. Health Belief Model: Need for More Utilization in Alcohol and Drug Education. Journal of Alcohol \& Drug Education, vol. 55.

[33] Sutton, S., 2005. Stage Theories of Health Behaviour. In Predicting Health Behaviour: Research and Practice with Social Cognition Models. Ed. by M. Conner, P. Norman. New York: Open University Press, 2005, pp. 223-275.

[34] Vilkonis, R., 2004. Vaiku kaip pésčiuju saugaus eismo kompetencijos ugdymas taikant eismo aplinkos tyrinejjima ir saugaus elgesio modeliavima: daktaro disertacija: socialiniai mokslai, edukologija (07 S). Šiauliai, Šiauliụ universitetas, 186 lap.

[35] Vitoria, P. D.; Salgueiro, M. F.; Silva, S. A.; De Vries, H., 2009. The impact of social influence on adolescent intention to smoke: Combining types and referents of influence. British Journal of Health Psychology, vol. 14, pp. 681-699. [accessed: 2013-11-18]. http://www.bpsjournals.co.uk.

[36] Weinstein, N. D.; Sandman, P. M.; Blalock, S. J., 2008. The Precaution Adoption Process Model. In Health behavior and health education: theory, research, and practice. Ed. by K. Glanz, B. K. Rimer, K. Viswanath. San Francisco: Jossey-Bass, 2008, pp. 123-147.

[37] WHO. Active Ageing. A Policy Framework, 2002. [accessed: 2013-11-18]. http://whqlibdoc.who.int/hq/2002/WHO_NMH_NPH_02.8.pdf

[38] Zaborskis, A.; Lenčiauskienė, I.; Klibavičius, A., 2005. Sveikatos stiprinimas mokykloje ir moksleivių gyvensena. Visuomenès sveikata, Nr. 2 (29), p. 34-40.

[39] Žardeckaitė-Matulaitienè, K., 2008. Rūkymo profilaktikos programos, pagristos socialinès itakos teoriniu modeliu, taikymo VI ir VIII klasiu mokiniams efektyvumas: daktaro disertacija: socialiniai mokslai, psichologija (06 S). Kaunas, Vytauto Didžiojo universitetas, 184 p.

[40] Želvienè, A., 2007. Moteru dalyvavimo atrankinèje mamografinèje patikroje saryšis su ju nuostatomis i krūties véži, krūtu savityrq ir mamografini ištyrima: daktaro disertacija: biomedicinos mokslai, visuomenès sveikata (10 B). Kaunas, Kauno medicinos universitetas, p. 135.

[41] McLeroy, K. R.; Bibeau, D.; Steckler, A.; Glanz, K., 1988. An ecological perspective on health promotion programs. Health Education Quarterly, Vol. 15, pp. 351-377.

[42] Stokos, D., 1996. Translating social ecological theory into guidelines for community health promotion. American Journal of Health Promotion, Vol. 10 (4), pp. 282-298. 